る.またCoの添加によ゙り固溶体および時効 硬度はほとんど影響をうけない。

(昭和 33 年 9 月寄稿)

$$
\text { 文献 }
$$

1) L. B. Pfeil, Mond Nickel Co.: British Patent, No. 58315? (1940)

2) J. W. Freeman et al.: Symposium on Plasticity \& Creep of Metals, ASTM, (1949)

3) W. C. Bigelow et al.: Proceeding ASTM, Vol. 56 (1956)

4) A. Taylor et al.: Journal of the Inst. of Metals, (1951 1952), (1952 53), (1954 55)

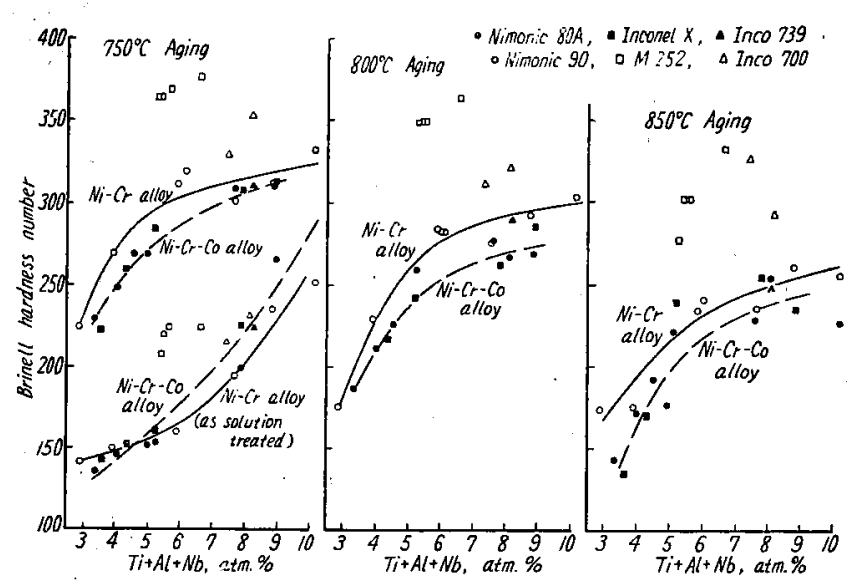

Fig. 7. Comparision of aging hardness between $\mathrm{Ni}-\mathrm{Cr}$ and $\mathrm{Ni}-\mathrm{Cr}-\mathrm{Co}$ alloys.

5) N.' J. Grant et al.: Jaurnal of Metals, Feb. (1953)

\& Nov. (1954), July (1957)

6) F. L. Ver Snyder: Trans. ASM., Vol. 45

7) W. Betteridge et a1.: Journal of Metals, July (1957)

\title{
高炭素鋼の黒鉛化におよぼす各種作用因子の影響について(その2)*
}

（高炭素鋼の黒鉛化に関する研究一I）

\author{
山中直道 ${ }^{* *} \cdot$ 日下邦 男 ${ }^{* * *}$

\section{Factors Controlling the Graphitization at Subcritical Temperature of High Carbon Steel (Part-2)}

\author{
(Study on the graphitization of high carbon steel-I) \\ Ndomichi Yamanaka, Dr. Eng. and Kunio Kusaka
}

Synopsis:

The authors studied other factors controlling the graphitization of high carbon steel at subcritical temperature in sequence of the first report (Tetsu-to-Hagané Vol. 44, No. $10 \mathrm{p}$ 1180). The results obtained were as follow:

(1) Cold deformation had an accelerating effect on graphitization and compressive forces were as effective as the tensile strength in promoting graphite formation.

(2) The heating at $870^{\circ} \mathrm{C}$ and furnace cooling after cold drawing inhibited markedly the graphitization on subsequent heating at $650^{\circ} \mathrm{C}$.

(3) Hydrogen, when used as annealing atmosphere at $650^{\circ} \mathrm{C}$, had a stabilizing effect on the carbide and inhibited graphite formation. Nitrogen atmosphere and vacuum had no effect of stabilizing carbide.

Cast iron chips used as packing material caused a less graphitization than nitrogen atmosphere or vacuum.

* 昭和 31 年 4 月本会講演大会にて講演 ** 特殊製銅株式会社 工博 *** 同, 研究所 


\section{I. 緒带}

著者らは前報において黒鉛化におよぼす加熱温度, 組 織，引抜加工度の影響などについて報告しセメンタイト の分解速度は $650^{\circ} \mathrm{C}$ において最大であること, まだ組 織はマルテンサイト状態のものが黑鉛化速度が最も大き く,パーライト組織がこれにつぎ球状化セメンタイト組 織のものが最も黑鉛化しにくいことおよび冷間引抜によ つて黑鉛化は促進され, 引抜加工度の大きいものほど黑 鉛化が速やがであることを述べた。これに引きつづいて 今回は冷間加工の種類, 引抜加工後の熱処理, 加熱雾囲 気の影響などについて報告する.

\section{II. 実 験 結 果}

（1）冷間加工の種類の影響について

冷間加工が黒鉛化を促進することは古くより知られた 事実1ー3であるが，冷間加工は大別すると冷間压延と冷 間引抜の二つになり，塑性変形にさいして加えられる応 力も, また残留応力の様相も異なつている. 冷間加工に 際して引張応力を受けた部分と在縮応力を受けた部分で 黒銛化促進現象に差異を生ずるか，あるいは加工度さえ 同一ならば加工方法に無関係に黒鉛化を促進するもの女 考えてよいか否かを確認するために実験を行つた。

まず生縮試片およびブリネル圧痕についての赛験を行 つた.すなわち球状化焼鈍を行つた $13 \phi$ 丸棒より10ф ×10試片を作成しこれを $1 / 2$ 高さに圧縮して鋳鉄ダラ イ粉中にて $650^{\circ} \mathrm{C} \times 100 \mathrm{~h}$ 加熱を行つた. その結果引 Photo. 1 の 1A, 1B の断面マク口組織に示す如く黒 鉛化がいちじるしく進行した. また球状化焼鈍を行つた $13 \phi$ 試片の断面中央部に $10 \mathrm{~mm}$ ボールにて $3000 \mathrm{~kg} の$ 荷重をかけて圧痕を生ぜしめ,これを $650^{\circ} \mathrm{C} \times 100 \mathrm{~h}$ 加 熱を行い中心部䓳断面のマク口組織を調查した. その結 果は Photo. 1C，1Dの加く圧痕直下では黒鉛の発生は あまりないが㾏下 $2 \mathrm{~mm}$ 程度の部分にいちじるしく 黒鉛の発生した部分があり，表面より6 mm深さになる ともはや压痕による変形がおよぼす黒鉛の発生はほとえ

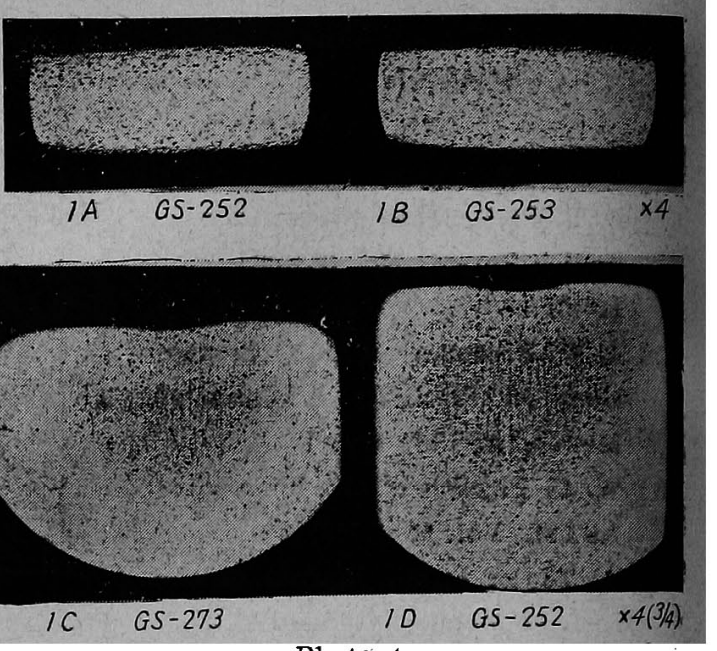

Photo. 1.

1 A, 1 B: Macrosections of specimens compressed to half height and heated for 100 hours at $650^{\circ} \mathrm{C}$.

$1 \mathrm{C}, 1 \mathrm{D}$ : Longitudinal section of deformed specimens with Brinell impression as heated for 100 hours at $650^{\circ} \mathrm{C}$.

どなくなる。

つぎに引張応力の影響をみるために電解鉄を原料とし

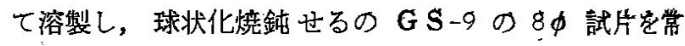
温にて引張り破断せしめた. このときの抗張力 $66 \mathrm{~kg} /$ $\mathrm{mm}^{2}$, 伸 $30.5 \%$, 絞り 50\% であつた.この破断試験 片を $650^{\circ} \mathrm{C} \times 34 \mathrm{~h}$ 加熱し，その絞り $40 \%$ の部分の組 織を調查したが Photo. 2 C に示す如く黑鉛炭素 $0.45 \%$ を示し，黑鉛化の促進されることを示す．さらに著者ら は球状化焼針を行つた試片より $9 \mathrm{~mm}$ 角 $\times 80$ 試片を作成 し, 内側半径 $10 \mathrm{~mm}$ にて曲け加工を行い破断寸前にて 中止し, $650^{\circ} \mathrm{C} \times 100 \mathrm{~h}$ 加熱を行い縦断面のマク口組織 を調查した. Photo. 2A，2B はその結果を示するの で曲げ加工の際に張力をうける外側部分および圧縮応力 をらける内側の部分共に黑鉛がいちじるしく発生したが 中心線に沿う部分にはほとんど黑鉛は形成されない。し たがつて压縮応力は引張応力と同様に黒鉛化を促進する

\begin{tabular}{|c|c|c|c|c|c|c|c|c|c|c|c|c|c|c|}
\hline \multirow{2}{*}{$\begin{array}{c}\text { Steel } \\
\text { No. }\end{array}$} & \multicolumn{13}{|c|}{ Chemical composition (\%) } & \multirow{2}{*}{ Remarks } \\
\hline & C & $\mathrm{Si}$ & $\mathrm{Mn}$ & $\mathrm{P}$ & S & $\mathrm{Ni}$ & $\mathrm{Cr}$ & $\mathrm{Cu}$ & $\mathrm{Sn}$ & $\begin{array}{l}\text { sol. } \\
\text { A1 }\end{array}$ & \begin{tabular}{|c|} 
insol. \\
$\mathrm{Al}$
\end{tabular} & $\Sigma \mathrm{Al}$ & $\Sigma \mathrm{N}_{2}$ & \\
\hline $\begin{array}{r}\mathrm{G} \mathrm{S}-252 \\
-253 \\
-273 \\
-\quad 9 \\
-231 \\
-172\end{array}$ & $\begin{array}{l}1.06 \\
1.06 \\
1.00 \\
1.09 \\
1.02 \\
0.98\end{array}$ & $\begin{array}{l}0.25 \\
0.26 \\
0.27 \\
0 \cdot 29 \\
0.29 \\
0.30\end{array}$ & $\begin{array}{l}\cdot 44 \\
\cdot 48 \\
\cdot 45 \\
\cdot 41 \\
\cdot 46 \\
\cdot 46\end{array}$ & $\begin{array}{l}.012 \\
.012 \\
.010 \\
.010 \\
.011 \\
.010\end{array}$ & $\begin{array}{l}.015 \\
.015 \\
.012 \\
.012 \\
.013 \\
.010\end{array}$ & $\begin{array}{l}\operatorname{tr} \\
\operatorname{tr} \\
\operatorname{tr} \\
\operatorname{tr} \\
\operatorname{tr} \\
\operatorname{tr}\end{array}$ & $\begin{array}{l}.02 \\
.02 \\
.02 \\
\operatorname{tr} \\
\operatorname{tr} \\
.02\end{array}$ & $\begin{array}{l}\mathrm{tr} \\
\mathrm{tr} \\
\cdot 04 \\
\mathrm{tr} \\
\mathrm{tr} \\
\mathrm{tr}\end{array}$ & $\begin{array}{l}.004 \\
.004 \\
.004 \\
\operatorname{tr} \\
.003 \\
.004\end{array}$ & $\begin{array}{l}\cdot 012 \\
.010 \\
.006 \\
.033 \\
.017 \\
.011\end{array}$ & $\begin{array}{l}.002 \\
.001 \\
.002 \\
.005 \\
.002 \\
.004\end{array}$ & $\begin{array}{l}.014 \\
.011 \\
.008 \\
.038 \\
.019 \\
.015\end{array}$ & $\begin{array}{l}.008 \\
.013 \\
.014 \\
.0058 \\
.010 \\
.028\end{array}$ & $\begin{array}{l}\text { Compression } \\
\text { test } \\
\text { ditio } \\
\text { Brinell impres- } \\
\text { sion test } \\
\text { Tensile test } \\
\text { Bending tegt } \\
\text { ditto }\end{array}$ \\
\hline
\end{tabular}



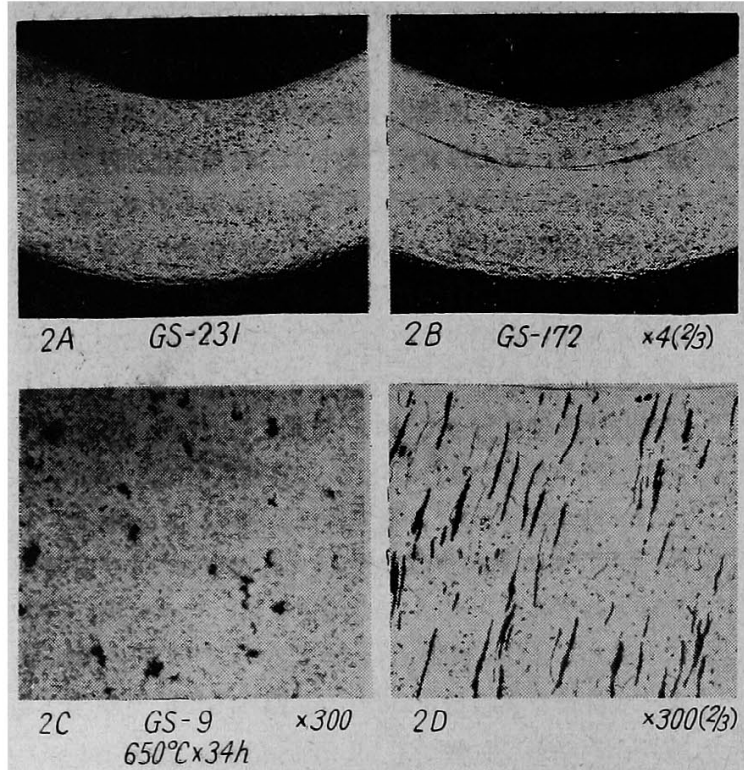

Photo. 2.

$2 \mathrm{~A}$ and $2 \mathrm{~B}$ : Sections showing effect of strains on graphitization of the cold bent specimen heated for 100 hours at $650^{\circ} \mathrm{C}$.

$2 \mathrm{C}$ : Microstructure, longitudinal section of the tensile-tested specimen at $40 \%$ reduction of area.

2D: Microstructure of graphitization appeared in high carbon steel strip for metalcutting band saws.

ことが明らかと炊つた。また冷間引拔が黒鉛化を促進す ることはすでに報告してあり以上のことより给間圧延, 引抜，引張，圧縮と方法の如何を問わず冷間加工を行うと 黒鉛化がいちじるしく促進されるということがいえる。

Photo. 2D浪間圧延品に現われた黒鉛化組織の一 例を示したもので C 1.06, Si 0.26, Mn 0.32, $\mathrm{Ni} \mathrm{0} 35, \mathrm{Cr} \mathrm{tr}, \mathrm{Cu} \operatorname{tr}, \mathrm{Sn} 0 \cdot 003$, 可溶 Al 0.064 $\%$ ，不溶 A1 0.004\%の化学成分を有する $2.55 \mathrm{~mm}$ 帯鋼を, 700 650 $\mathrm{C}$ で中間㜔鈍を 4 回行つて 0.6 $\mathrm{mm}$ に冷間圧延したものである.この場合には可溶 $\mathrm{Al}$ の量がいちじるしく多くまた $\mathrm{Ni}$ の多いことが 黑鉛化を促進したものと考えられるが，これら合金 元素の影響については後報する。

（2）引抜加工の後処理の影響

前実験において水冷してマルテンサイト状態にし たものを変態点以上に加熱すると，これによつて黑 鉛核の一部が破壊されるものと考学られ，650 $\mathrm{C}$ の 黒鉛化の進行をいちじるしく阻止することが判明し た. しからば $10 \phi \rightarrow 8 \phi$ に冷間引拢安行つた後に
変態点以上に加熱した場合には，その後の黑鉛化に如， 何なる影響を有するかについて実験を行つた。すなか ち電解鉄を原料として溶製した GS-134，-24，-7 に ついて球状化焼鈍後 $10 \phi$ に加工してこれを $8 \phi$ に引 抜き加工した後 $780^{\circ} \mathrm{C}$ 打よび $870^{\circ} \mathrm{C} に 1 \mathrm{~h}$ 加熱して 恼冷し，つぎ $650^{\circ} \mathrm{C} \times 24 \mathrm{~h}$ の加熱老行い黑鉛析出 量を分析に上り求めた. この結果は Fig. 1 (A)に示 す如くであつて $780^{\circ} \mathrm{C} \times 1 \mathrm{~h}$ 加熱を行うことによって 黒鉛宸素量は半減し，また $870^{\circ} \mathrm{C} \times 1 \mathrm{~h}$ 加熱灾行つた ものはほとんど黑鉛は痕跡となる.すなわち引抜加工. を行つた場合でも変態点以上に加熱すると冷間加工の 霆に基因方ると考光られる所の黑鉛核の一部を無圱に 乙て黒鉛の発生を滅少せしぬ, この効果は変態点以上 加熱温度の高いほど大である．なお同樣の䒠験を砂鉄 系原料を用いた場合についても行つたがこの結果は （B）に示寸如く，8 $\phi$ 引披加工後に変態点以上に加熱 すると $650^{\circ} \mathrm{C} \times 100 \mathrm{~h}$ 加熱後の硬度も大となり黑鉛析 出る減少する. Photo. 3 は GS-196 についての断面マ ク口組織を示し引抜後 $780^{\circ} \mathrm{C} \times 2 \mathrm{~h}$ 悷冷処理をしたもの は引抜のままの場合よりは析出黒鉛量は少ないが，引摭 加工を行わずして $780^{\circ} \mathrm{C}$ 焼鈾のまま扰よび $870^{\circ} \mathrm{C}$ 空冷 のままのものを $650^{\circ} \mathrm{C} \times 100 \mathrm{~h}$ 加熱した場合よりも黑鉛 化はかなり促進されている。 このことは引拔加工を行つ たのちに $780^{\circ} \mathrm{C}$ まで加熱するまでの過程においてすで に黒鉛核が生成されて抢ることを示し，この一部が变態 点以上の加熱に上つて無效にされるすのであるう。

\section{（3）加熱雾囲気の影響}

黒鉛化におよぼす加熱雾囲気の影響についてはすでに 二，三の報告がある.すなおち Brown \& Hawkesむ) は 鋳鉄についての研究において加熱雾囲気に水素を用いる

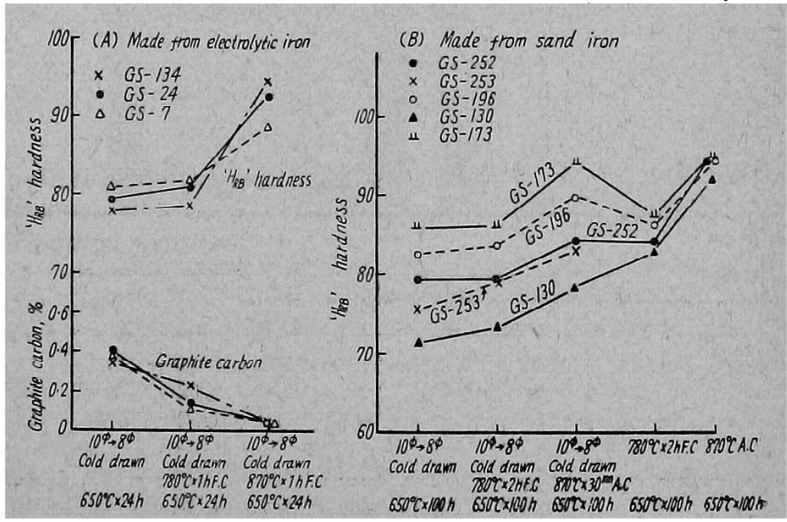

Fig. 1. Effect of various treatments on the graiphitzation after cold-drawn from $10 \phi$ to $8 \phi$. Heated 24 hours (A) and 100 hours (B) at $650^{\circ} \mathrm{C}$. 


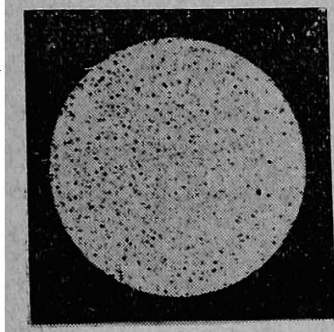

$3 A$

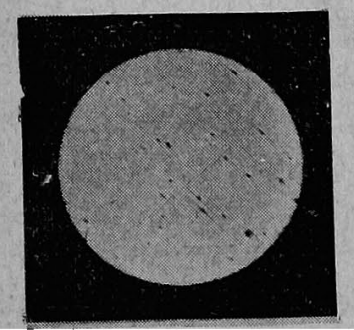

$3 C$

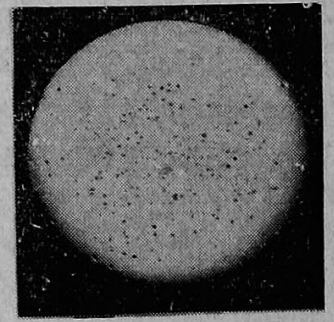

$3 B$

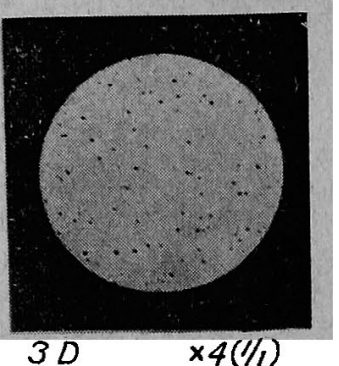

3A: Cold drawn from $10 \phi$ to $8 \phi$

$3 B$ : Cold drawn from $10 \phi$ to $8 \phi$, and furnace-cooled from $780^{\circ} \mathrm{C} \times 2 \mathrm{~h}$

3C: Furnace cooled from $780^{\circ} \mathrm{C} \times 2 \mathrm{~h}$

3D: Air cooled from $870^{\circ} \mathrm{C}$

Photo. 3. Macrosections of GS-196 steel heated for 100 hours at $650^{\circ} \mathrm{C}$ after various treatments.

々炭化物を安定化し黑鉛形成を阻止することを発表し， また Palmer ${ }^{5)}$ も加熱雾目気に水素が存在すると可鈝鋳 鉄のセメンタイト分解速度を遅くすることを報告してい る.,E. D. Harry6) は低炭素珪素鋼について冷問压延後 の変態点下加熱雾同気として乾懆窒素, 乾燥水素および 真空を用いて試験を行つた。その結果水素ガスおよび真 空が窒素ガス中に比して黒鉛化速度が遅いことを認め, この場合窒素ガス中で黒鉛化が促進されたのは共存して いた微量の酸素の影響によるものであり，中性抢よび還 元性雲园気が黑鉛化を阻止する効果を有するものとして いる.また Dennis? は重共析鋼の黑鉛化に関して実験
を行い酸化性雾团気が黒鉛化を促進するのにいちじるし 々効果を有し，真空中および窒素中での加熱肪空気中加 熱の場合に比して黑鉛化速度がいちじるしく遅いことを 述べている．以上は文献にあらすれた黒鉛化加熱雾园效 の影響であるがまだ明確ならざる点もあるので，著者ら は加熱雾囲気を水素, 空素, 真空と変化せしぬまた銆鉄 ダライ粉充填中で行つた場合との比較を行つた. 供試材. は吵鉄系原料岕用いて熔製せるもので $11 \phi$ に加工して $870^{\circ} \mathrm{C}$ より水冷してマルテンサイト状態にしたものおよ び球状化焼鍍を行つて $10 \phi$ に加工しこれを $8 \phi$ に引抜 加工を行つたものをそれぞれの雾围気中にて $650^{\circ} \mathrm{C} \times$ $100 \mathrm{~h}$ の加熱を行つた. 真空注油拡散ポンプを用いて 1 $\sim 5 \times 10^{-5} \mathrm{mmHg}$ 程度で行い，また水素および窒素市 スはそれぞれボンベよりの途中に执いて $\mathrm{CaCl}_{2} ， \mathrm{P}_{2} \mathrm{O}_{5}$ にて脱水し, $\mathrm{Cu}$ 粉末, $\mathrm{Ti}$ 粉末 $\left(\mathrm{H}_{2}\right.$ の場合 $), \mathrm{Mg}$ 粉 末にて酸素它吸収せしめた． $650^{\circ} \mathrm{C} \times 100 \mathrm{~h}$ 加熱後のス ケールの発生は皆無でありいずれも光輝焼鈍状態を示し た.また鉄容器中に鋳鉄ダライ粉を充償した場合につい ても酸化膜の発生はほとんど認められなかつた。

A) マルテンサイト状態のものの黒鉛化

供試材は Table 3 に示す如きもので球状化焼鈷後 $11 \phi \times 30$ に加工せる試片を $870^{\circ} \mathrm{C}$ より水冷したものを 用いた. Fig. 2 (A), (B) は $650^{\circ} \mathrm{C} \times 100 \mathrm{~h}$ の加熱後の 硬度におよぼす加熱雾囲気の影響を示したもので水素中 にて加熱せるものが最も硬度高く鋳鉄ダライ粉中で加熱 したものがこれにつき，空気中，空素中，真空中，の順 に硬度は低下する. Photo. 4 は各雾囲気中で加熱した 試片のマクロ組織を示するので鋳鉄ダライ粉中および窒 素中で加熱したものはいちじるしい黑鉛化を示すが水素 中で加熱を行つたものにはほとんど黑鉛は発生しない。 真空中および空気中加熱のものは等素ガス中加熱のもの とほとえど同程度の黒鉛化を示し，鋳鉄ダライ粉中加熱 のものは窒䒺中加熱の場合に比較すると黑鉛の発生はい

Table 2. Chemical composition of steels tested.

\begin{tabular}{|c|c|c|c|c|c|c|c|c|c|c|c|c|c|}
\hline \multirow{2}{*}{ Steel No. } & \multicolumn{13}{|c|}{ Chemical composition (\%) } \\
\hline & $\mathrm{C}$ & $\mathrm{Si}$ & $\mathrm{Mn}$ & $\mathbf{P}$ & S & $\mathrm{Ni}$ & $\mathrm{Cr}$ & $\mathrm{Cu}$ & Sn & sol. A1 & insol. & $\Sigma \mathrm{A} 1$ & $\Sigma \mathbf{N}_{2}$ \\
\hline $\begin{array}{r}\mathrm{G} \cdot \mathrm{S}-134 \\
-24 \\
-\quad 7\end{array}$ & $\begin{array}{l}1 \cdot 06 \\
1 \cdot 08 \\
1 \cdot 16\end{array}$ & $\begin{array}{l}\cdot 23 \\
\cdot 28 \\
\cdot 35\end{array}$ & $\begin{array}{l}\cdot 42 \\
\cdot 42 \\
\cdot 43\end{array}$ & $\begin{array}{l}.012 \\
.008 \\
.010\end{array}$ & $\begin{array}{l}.015 \\
.010 \\
.010\end{array}$ & $\begin{array}{l}\mathrm{tr} \\
\mathrm{tr} \\
\mathrm{tr}\end{array}$ & $\begin{array}{l}\cdot 01 \\
\operatorname{tr} \\
\operatorname{tr}\end{array}$ & $\begin{array}{l}\operatorname{tr} \\
\operatorname{tr} \\
\operatorname{tr}\end{array}$ & $\begin{array}{l}\operatorname{tr} \\
\operatorname{tr} \\
\operatorname{tr}\end{array}$ & $\begin{array}{l}\cdot 058 \\
\cdot 033 \\
.030\end{array}$ & $\begin{array}{l}\cdot 004 \\
\cdot 004 \\
\cdot 012\end{array}$ & $\begin{array}{l}.062 \\
.037 \\
.042\end{array}$ & $\begin{array}{l}.008 \\
.0069 \\
.0080\end{array}$ \\
\hline $\begin{array}{r}\text { G S }-130 \\
-173 \\
-196 \\
-252 \\
-253\end{array}$ & $\begin{array}{l}1 \cdot 06 \\
0.98 \\
1 \cdot 02 \\
1.06 \\
1.06\end{array}$ & $\begin{array}{l}\cdot 24 \\
.28 \\
.24 \\
.25 \\
.26\end{array}$ & $\begin{array}{r}\cdot 44 \\
\therefore \cdot 43 \\
\cdot 44 \\
\cdot \cdot 44 \\
\because \cdot 48\end{array}$ & $\begin{array}{l}.008 \\
.011 \\
.009 \\
.012 \\
.012\end{array}$ & $\begin{array}{l}.019 \\
.014 \\
.011 \\
=015 \\
.015\end{array}$ & $\begin{array}{l}\operatorname{tr} \\
=01 \\
\operatorname{tr} \\
\operatorname{tr} \\
\operatorname{tr}\end{array}$ & $\begin{array}{l}\operatorname{tr} \\
.02 \\
.02 \\
.02 \\
.02\end{array}$ & $\begin{array}{l}\cdot 01 \\
\operatorname{tr} \\
\operatorname{tr} \\
\operatorname{tr} \\
\operatorname{tr}\end{array}$ & $\begin{array}{l}\cdot 004 \\
\cdot 004 \\
\cdot 003 \\
\cdot 004 \\
\cdot 004\end{array}$ & $\begin{array}{l}.054 \\
.010 \\
.021 \\
.012 \\
.001\end{array}$ & $\begin{array}{l}\cdot 003 \\
.003 \\
.006 \\
.002 \\
.001\end{array}$ & $\begin{array}{l}.057 \\
.013 \\
.027 \\
.014 \\
.011\end{array}$ & $\begin{array}{l}.017 \\
.021 \\
.008 \\
.013\end{array}$ \\
\hline
\end{tabular}


Table 3. Chemical composition of steels tested.

\begin{tabular}{|c|c|c|c|c|c|c|c|c|c|c|c|c|c|}
\hline \multirow{2}{*}{ Steel No. } & \multicolumn{13}{|c|}{ Chemical composition $(\%)$} \\
\hline & C & $\mathrm{Si}$ & $\mathrm{Mn}$ & $P$ & $\mathrm{~S}$ & $\mathrm{Ni}$ & $\mathrm{Cr}$ & $\mathrm{Cu}$ & $\mathrm{Sn}$ & sol. A1 & insol A1 & $\Sigma \mathrm{Al}$ & $\Sigma \mathrm{N}_{2}$ \\
\hline $\begin{array}{r}\text { G S }-255 \\
-267\end{array}$ & $\begin{array}{l}0.98 \\
0.97\end{array}$ & $\begin{array}{l}\cdot 27 \\
\cdot 28\end{array}$ & $\begin{array}{l}\cdot 10 \\
.47\end{array}$ & $\begin{array}{l}.011 \\
.010\end{array}$ & $\begin{array}{l}.015 \\
.015\end{array}$ & $\begin{array}{l}\text { tr } \\
\text { tr }\end{array}$ & $\begin{array}{l}.02 \\
.01\end{array}$ & $\begin{array}{l}\operatorname{tr} \\
\operatorname{tr}\end{array}$ & $\begin{array}{l}.005 \\
.003\end{array}$ & $\begin{array}{l}.019 \\
.006\end{array}$ & $\begin{array}{l}.002 \\
.002\end{array}$ & $\begin{array}{l}.021 \\
.008\end{array}$ & $\begin{array}{l}.009 \\
.016\end{array}$ \\
\hline $\begin{array}{r}\text { G S }-121 \\
-99 \\
-196 \\
-98 \\
-100 \\
-256 \\
-213\end{array}$ & $\begin{array}{l}.98 \\
1 \cdot 19 \\
1.02 \\
1 \cdot 01 \\
1 \cdot 07 \\
0.91 \\
0.96\end{array}$ & $\begin{array}{l}\cdot 32 \\
\cdot 30 \\
\cdot 24 \\
\cdot 30 \\
\cdot 30 \\
\cdot 26 \\
\cdot 32\end{array}$ & $\begin{array}{l}\cdot 36 \\
\cdot 46 \\
\cdot 44 \\
\cdot 48 \\
\cdot 47 \\
\cdot 19 \\
\cdot 54\end{array}$ & $\begin{array}{l}.007 \\
.008 \\
.009 \\
.006 \\
.007 \\
.012 \\
.008\end{array}$ & $\begin{array}{l}\cdot 016 \\
\cdot 017 \\
\cdot 011 \\
\cdot 018 \\
\cdot 017 \\
\cdot 014 \\
\cdot 018\end{array}$ & $\begin{array}{l}\operatorname{tr} \\
\operatorname{tr} \\
\operatorname{tr} \\
\operatorname{tr} \\
\operatorname{tr} \\
\operatorname{tr} \\
\operatorname{tr}\end{array}$ & $\begin{array}{l}.02 \\
.02 \\
.02 \\
.01 \\
.02 \\
.01 \\
\operatorname{tr}\end{array}$ & $\begin{array}{r}\cdot 02 \\
\operatorname{tr} \\
\operatorname{tr} \\
\cdot 01 \\
\cdot 03 \\
\operatorname{tr} \\
\cdot 02\end{array}$ & $\begin{array}{l}.003 \\
.003 \\
.003 \\
.004 \\
.005 \\
.004 \\
.005\end{array}$ & $\begin{array}{l}.006 \\
.016 \\
.021 \\
.045 \\
.076 \\
.016 \\
.015\end{array}$ & $\begin{array}{l}.003 \\
.003 \\
.006 \\
.002 \\
.005 \\
.002 \\
.003\end{array}$ & $\begin{array}{l}.009 \\
.019 \\
.027 \\
.047 \\
.081 \\
.018 \\
.018\end{array}$ & $\begin{array}{l}.025 \\
.026 \\
.021 \\
.025 \\
.008 \\
.013\end{array}$ \\
\hline
\end{tabular}
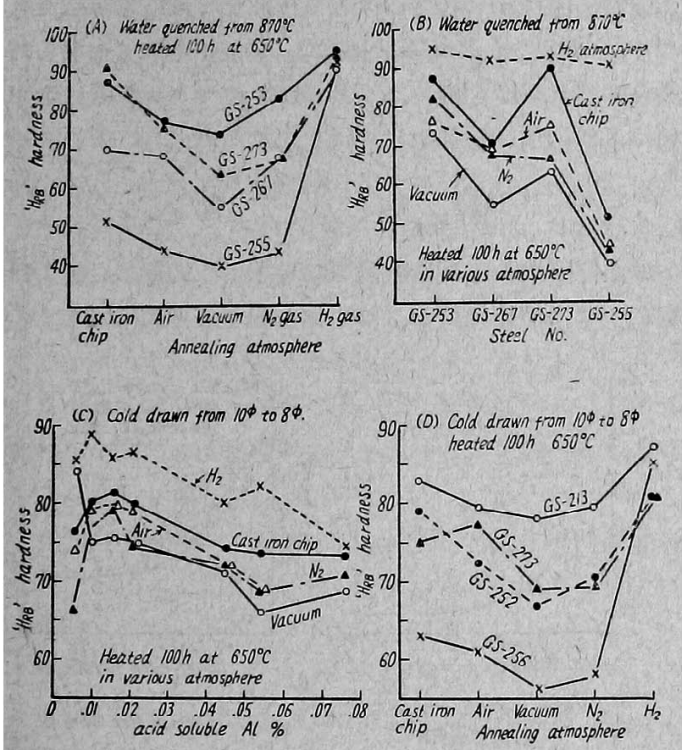

Fig. 2. Effect of heating atmosphere on the hardness of steels heated for 100 hours at $650^{\circ} \mathrm{C}$ after water-quenching and cold drawing.

くらが少ない.

B) 冷間引抜後の黑鉛化

つぎに $10 \phi \rightarrow 8 \phi$ 冷間引抜後同じように加熱雲囲気を かえて実験を行つたが $650^{\circ} \mathrm{C} \times 100 \mathrm{~h}$ 加熱後の RB 硬度 は Fig. 2 (C) (D) の如くである. (C) 図は可溶 A1 と各䨌囲気中加熱後の硬度との関係を示すもので水素中 加熱のむのが最も硬度高く鋳鉃ダライ粉中加熱のものが これについでいる. 水素中加熱の場合の硬度が高いのは 黒鉛化の進行がほとえど阻止されるからであるが可溶 A1 が多くなると水素の黒鉛化阻止効果も小さく，功な りの黒鉛量を析出するようになる. Photo. 5 はマクロ 組織を示すむので水素中加熱の場合は黑鉛化がいちじる しく阻止されるが，GS-130 㤝可溶 A1 0.054\% 含有

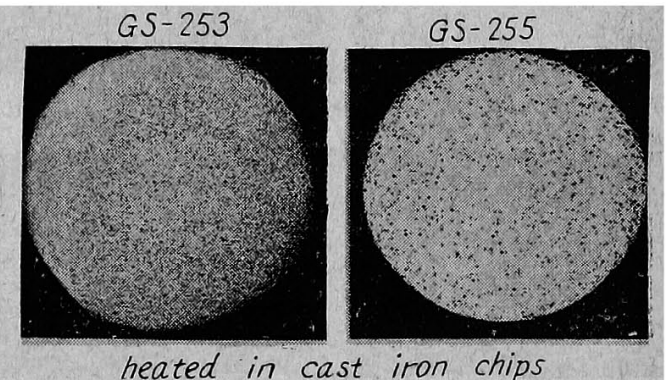

heated in cast iron chips
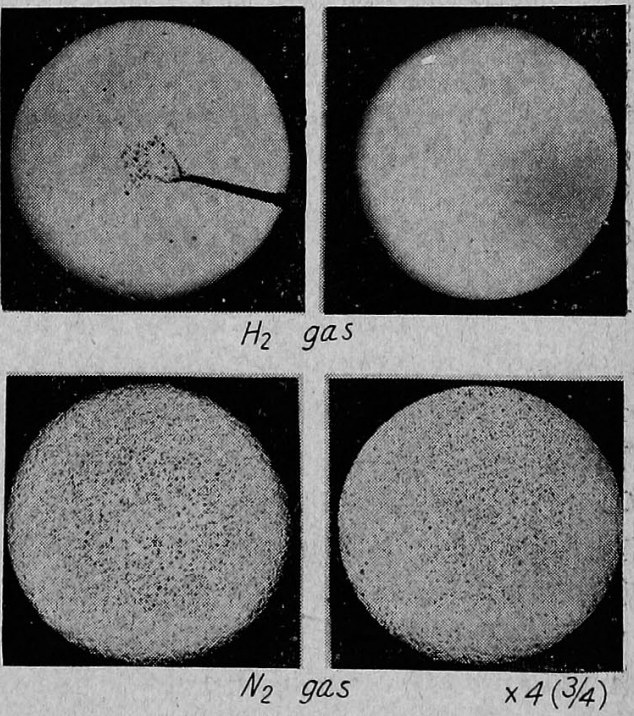

Macrostructures of GS-253 and 255 steel heated for 100 hours at $650^{\circ} \mathrm{C}$ after water-quenching from $870^{\circ} \mathrm{C}$

Photo. 4. Effect of annealing atmosphere on the graphitization.

するために水絜中加熱のものもかなりの黑鉛を析出して いる. 空気中および真空中加熱の場合は窒素ガス中の場 合とほとえど同程度の黒鉛化を示した.

以上マルテンサイト状態招よび冷間引抜状態のものの

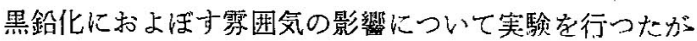




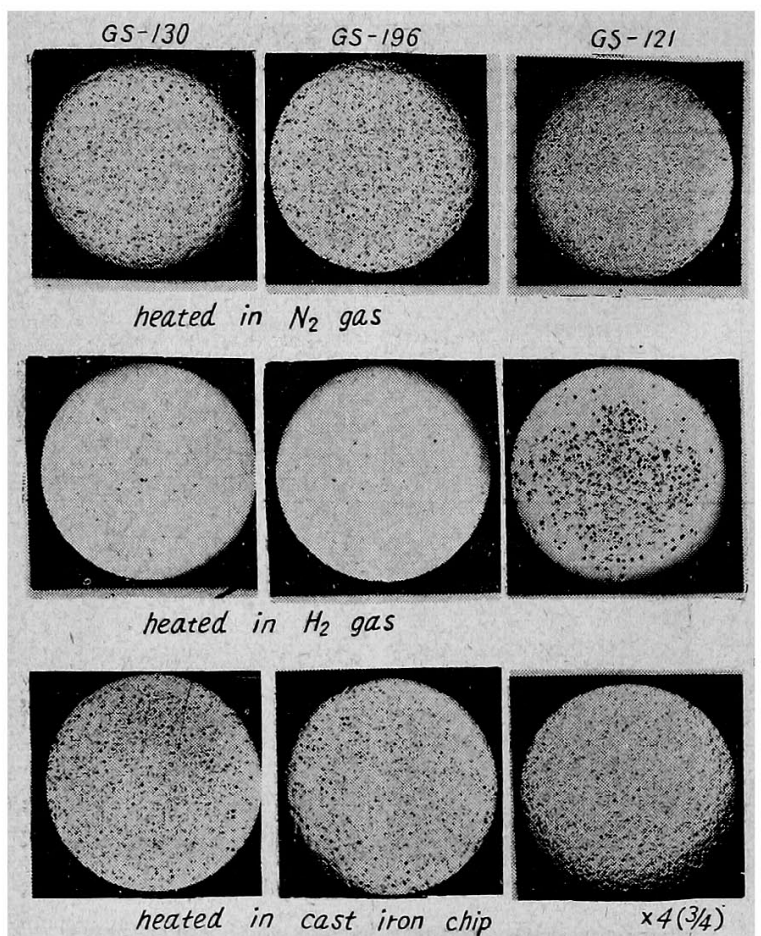

Macrostructures of GS-121, -196 and -130 steel heated for 100 hours at $650^{\circ} \mathrm{C}$ after cold-drawing from $10 \phi$ to $8 \dot{\phi}$ ( $35 \%$ reduction)

Photo. 5. Effect of annealing atmosphere on the graphitization.

水菜ガスの黑鉛化阻止の効果が顕著であることが判明し た. 真空中および窒素中での加熱任黑鉛化阻止の効果を 示さず空気中加熱の場合とほとんど同程度の黑鉛化を示 す. 鋳鉄ダライ粉中加熱では等囲気は $\mathrm{CO}+\mathrm{CO}_{2}+\mathrm{N}_{2}$ に なつており8) 空気中および窒素中での加熱の場合より黑 鉛化速度はやや遅くなる。

C) 液体㑢炭空化剂中での加熱

電解鉄を原料として愹製したもの，および砂鉄系原料 を用いて真华熔解せるものについて $870^{\circ} \mathrm{C}$ 水冷後およ

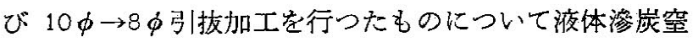
化剂 $\mathrm{NaCN}-\mathrm{Na}_{2} \mathrm{CO}_{3}$ ソルト (LC-3) 中にて $650^{\circ} \times 24$ h加熱を行い組織, 硬度の測定を行つた。このソルトは 浴が大気中の $\mathrm{O}_{2}$ を溶解して $4 \mathrm{NaCN}+4 \mathrm{O}_{2}=2 \mathrm{Na}_{2} \mathrm{CO}_{3}$

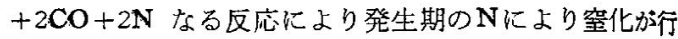
われる. 温度が $650^{\circ} \mathrm{C}$ では滲炭はほとえど行われね. この結果はいずれも表層に0.5〜1 mm 程度のセメンタ イトの安定なリムを生じこの部分ではほとんど黒鉛化が 生ぜず内部にゆくにつれて黑鉛化が進行していることが わかる.Fig. 3(A)，(B) は断面の硬度曲線を示したも ので表面より内部にゆくにつれて硬度が低下している。 すな⿰ち $\mathrm{NaCN}-\mathrm{Na}_{2} \mathrm{CO}_{3}$ ソルト中にて $650^{\circ} \mathrm{C} \times 24 \mathrm{~h}$ の

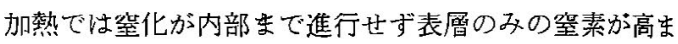
りこの部分の黑鉛化が阻止されたものと考えられる.

Fig. 3(C)，（D） は砂鉄系原料を用いて熔製したもの について同様に $650^{\circ} \mathrm{C} \times 100 \mathrm{~h}$ 加熱後の硬度を示したも ので, いずれも $\mathrm{NaCN}-\mathrm{Na}_{2} \mathrm{CO}_{3}$ ソルト中にて加熱した 場合の方が硬度も高く，Photo.6のマクロ組織に示す 如く黑鉛化がいちじるしく阻止される.

\section{III. 結言}

以上電解鉄および砂鉄系原料定用いて熔製した純炭素 鋼について黒鉛化におよぼす作朋因子の巾, 冷間加工の

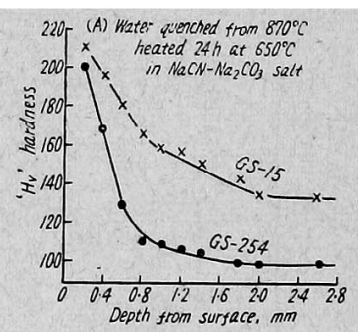

(c) Water quenched from $870^{\circ} \mathrm{C}$

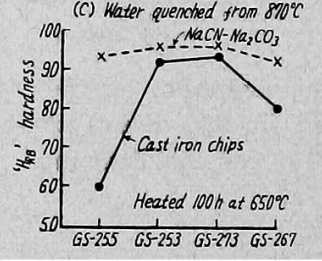

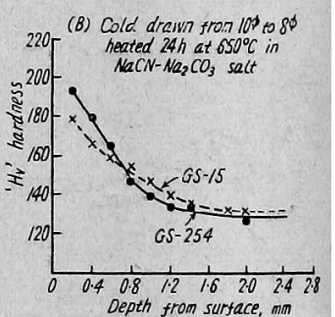

Depth from surface, $\mathrm{mm}$

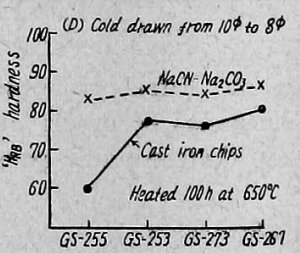

Fig. 3 A, B: Hardness distribution curves heated for 24 hours in $\mathrm{NaCN}-\mathrm{Na}_{2} \mathrm{CO}_{3}$ salt at $650^{\circ} \mathrm{C}$ after water-quenching (A) and cold-drawn (B)

C, D: Hardness after $650^{\circ} \mathrm{C} \times 100 \mathrm{~h}$ heating in cast iron chips and $\mathrm{NaCN}-$ $\mathrm{Na}_{2} \mathrm{CO}_{8}$ salt.

Table 4. Chemical composition of steels tested.

\begin{tabular}{|c|c|c|c|c|c|c|c|c|c|c|c|c|c|}
\hline \multirow{2}{*}{ Steel No. } & \multicolumn{13}{|c|}{ Chemical composition (\%) } \\
\hline & $\mathrm{C}$ & $\mathrm{Si}$ & $\mathrm{Mn}$ & $\mathrm{P}$ & $\mathbf{S}$ & $\mathrm{Ni}$ & $\mathrm{Cr}$ & $\mathrm{Cu}$ & $\mathrm{Sn}$ & sol. Al & insol. Al & $\Sigma \mathrm{A} 1$ & $\Sigma \mathrm{N}_{2}$ \\
\hline $\begin{array}{l}\mathrm{G} S-15 \\
\mathrm{G} S-254\end{array}$ & $\begin{array}{l}1 \cdot 07 \\
0.90\end{array}$ & $\begin{array}{l}\cdot 25 \\
\cdot 23\end{array}$ & $\begin{array}{l}\cdot 38 \\
\cdot 23\end{array}$ & $\begin{array}{l}.012 \\
.010\end{array}$ & $\begin{array}{l}.010 \\
.015\end{array}$ & $\begin{array}{l}\operatorname{tr} \\
\operatorname{tr}\end{array}$ & $\begin{array}{l}\mathrm{tr} \\
.02\end{array}$ & $\begin{array}{l}\operatorname{tr} \\
\operatorname{tr}\end{array}$ & .003 & $\begin{array}{l}.010 \\
.014\end{array}$ & $\begin{array}{l}.004 \\
.001\end{array}$ & $\begin{array}{r}.014 \\
.015\end{array}$ & $\begin{array}{l}.0055 \\
.003\end{array}$ \\
\hline
\end{tabular}


種類の影㗽, 引抜加工後の処理の影響, 加熱雾囲気の影 響について実験を行つたが結果を要約すればつぎの如く である.

（1）压縮応力は引張応力と同程度に黒鉛化を促進し 冷間圧延, 引抜, 引張, 圧縮と方法の如何安問わず冷間 加工を行うと黑雓化を促進する.

（2）引报加工行つた後変態点以上に加熱を行う之 引つづいて行われる $650^{\circ} \mathrm{C}$ の加熱你しての黑鉛化を かなり阻止するが冷間加工を行わない場合に比すれば析 出黑鉛量は多い。このことは引拔加工を行つたのち变態 点まで加熱する過程においててずに黑鉛核が生成されて おり，変態点以上に加熱するとこの核の一部が無効にさ れるものと考えられる。

（3） マルテンサイト状態および冷間引拔状態のもの

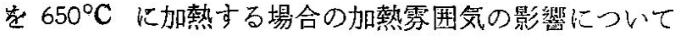
実験を行つた結果は水素がいちじるしく黑鉛化を阻止す ることが判明した．真空中および窒素中での加熱は黒鉛 化阻止の効果示さず空気中加熱の場合と同程度の黑鉛 化を示す．鋳鉄ダライ粉中加熱では空気中および窒素中 での加熱の場合よりも黑鉛化速度はやや遅くなる.

また $650^{\circ} \mathrm{C} の \mathrm{NaCN}-\mathrm{Na}_{2} \mathrm{CO}_{3}$ 液体渗炭窒化削中で 加熱した場合には発生期の $\mathrm{N} か ゙$ 掘散漫入し黑鉿化をいち ビるしく阻止することが判明した。

終りに本研究の発表を許可されたる石原工場長に敬意 を表すると共に実験の一部を担当された外岡耀係員伅謝 意を表します。(昭和 33 年 8 月寄稿)

$$
\text { 文献 }
$$

1) J. H. Andrew \& H. Lee. J. Iron \& Steel Inst. Vol. 165 (1950) p. 145 184

2) R. Austin, M. C. Fetzer. T. ASM. Vol. 35 (1945) p. 485 535

3) B. S. Norris: T. ASM. Vol. 37 (1946)

Discussion. p. $129 \sim 133$

4) F. Brown \& M. F. Hawkes: T. Amer.

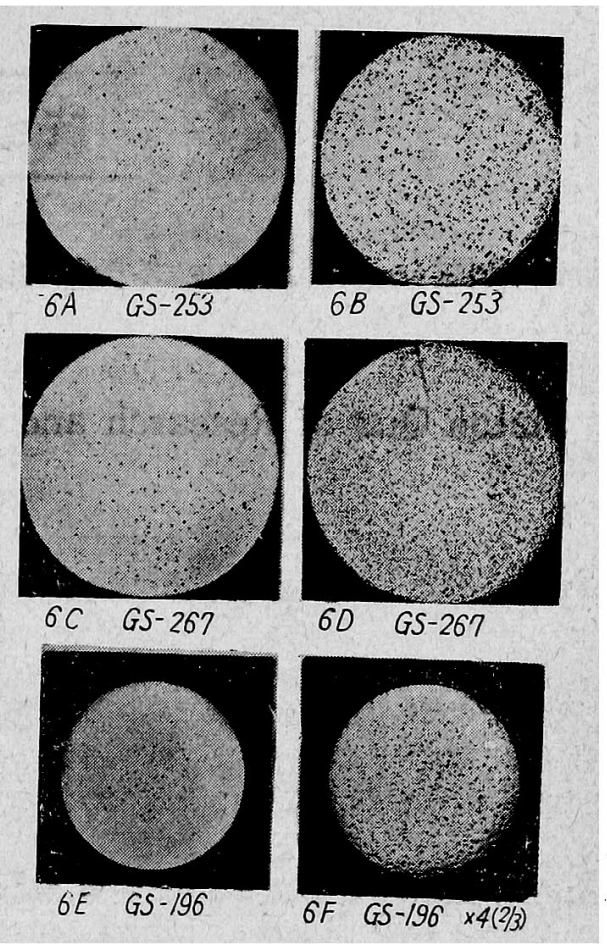

Heated 100 hours at $650^{\circ} \mathrm{C}$ after water quenching $(A, B, C, D)$ and cold drawing from $10 \phi$ to $8 \phi(E, F)$. $A, C$ and $E$ : heated in $\mathrm{NaCN}-\mathrm{Na}_{2} \mathrm{CO}_{3}$ salt

B,D and $F$ : heated in cast iron chips

Photo. 6. Effect of annealing atmosphere on the graphitization.

Found. Soc., Vol. 60 (1952) p. 635 639

5) S. W. Palmer: Brit. C. I. Res. Assoc, J. Res. Dev. Vo'. 5 (1953) p. 26〜37

6) E. D. Harry: J. of Iron \& Steel. Oct. 1954 p. $109 \sim 112$

7) W. E. Dennis: J. Iron \& Steel Inst. (1952) Vol. 171 p. $59 \sim 63$

8) 呂㻣石: 金学誌, Vol. 8 (1944) p. 605〜627 